\title{
Financial Globalisation and Poor Countries: The Impact of International Asset Demand Instability on Emerging Markets
}

\author{
Valpy FitzGerald*
}

\section{Introduction}

The expansion and contraction of portfolio capital flows from the global financial centres towards emerging markets over the past decade has generated considerable controversy over their underlying economic determinants, and by extension their instability: there is growing evidence that these are related to conditions in the financial markets of developed countries (FitzGerald 2002). The resulting asset bubbles have a serious impact on the real economy in developing countries even in the presence of low inflation, fiscal balance and monetary rectitude (IMF 2000). More seriously, such fluctuations degrade income distribution and social services, thus exacerbating poverty problems (FitzGerald 2001). Nonetheless, orthodox policy design by international financial institutions such as the International Monetary Fund (IMF) and the World Bank still focuses on the conditions in emerging ("host") markets themselves - often known as "fundamentals" - rather than the determinants of the demand in developed ("home") countries for emerging market securities as an asset class.

The economic theory of international capital markets is still in its infancy, in marked contrast to the sophistication of the microeconomics of portfolio choice. Sticky prices, market segmentation, heterogeneous investors, persistent currency misalignments despite arbitrage and the cost of scarce information all need to be accounted for if the model is even to approximate the real world in a useful way (Dumas 1994). In marked contrast, the framework that informs policy debate appear to reflect, in essence, a simple microeconomic portfolio composition rule based on given relative returns and risks of various assets. Policy in developing countries is then directed towards reducing the risk of and increasing the return in these assets by appropriate macroeconomic regimes, liberalisation strategies and property guarantees. However, neither the internal dynamics of capital markets - particularly the tendency to endogenous asset bubbles - nor the consequences of external shocks such as US interest rates, are not seen as relevant objectives for international development policy.

Recent academic literature has begun to emphasise home market factors such as interest rates, changing risk appetite, herding behaviour and momentum trading. However, attempts to model these flows have revealed difficulties in separating home from host factors - or "push" and "pull" effects as they are conventionally known. This is because aggregate flows and yield spreads do not simply reflect an underlying microeconomic process of portfolio allocation, based on known risk and return characteristics of emerging markets in relation to wealth and riskless return on the investors' own market. At the macroeconomic level aggregate market behaviour is such that:

1. International capital markets do not fully clear - in the sense that even at equilibrium some borrowers are "rationed out" and cannot borrow 
at any rate of interest - so that demand fluctuations are reflected in unstable flows rather than smooth price adjustment. ${ }^{1}$

2. Capital flows themselves affect asset prices both directly (by creating and collapsing asset price bubbles) and indirectly (through increasing or decreasing default risk).

3. Observed asset yields can have apparently perverse effects on flows because of the risk premium they contain, so that higher yields are associated with reduced flows.

4. The changing level of investor risk appetite on the home market affects both asset prices (which include a default risk premium) and capital flows themselves (through credit rationing).

In consequence, "getting the fundamentals right" - such as reduced government expenditure, restrictive monetary policy, public enterprise privatisation or liberalisation of trade and finance - may not be sufficient for open developing countries to avoid balance of payments instability. This article attempts to encompass these notions formally and to test them empirically for US purchases of emerging market sovereign bonds, and thus lead to a revision of policy recommendations.

\section{The state of the art in modelling capital flows to developing countries}

Since the early 1990s, when the surge of capital flows to emerging markets got underway, the academic research literature has begun to reveal the importance of these factors, which reflect fluctuations in developed country demand for developing country assets. Calvo et al. (1993) observed that Latin American reserves and exchange rates (as a proxy for capital flows) move together and concluded that common external shocks are a major determinant of capital inflows. ${ }^{2}$ FernandezArias (1996) addressed the determination of country risk as the channel through which exogenous shocks are transmitted to portfolio inflows, finding that external ("push") factors have a substantial impact on creditworthiness as reflected in the secondary market debt prices. Montiel and Reinhart (1999) examined the volume and composition of capital inflows to developing countries and conclude that international interest rates have an important effect on not only the level of flows but also the balance between bonds, equity and bank credit. Montiel and Reinhart (2001) suggested that in addition there are "step" effects arising from the progressive integration of developing countries to global capital markets that make them more sensitive to international interest rates. Finally, Mody et al. (2001) included a wider range of push factors (i.e. asset demand fluctuations) than US growth and interest rates - particularly US high-yield spreads ${ }^{3}$ as a proxy for risk aversion. They conclude that in general, pull factors are more important in the longrun but that push factors are determinant in shortrun dynamics. They treat bond yields exogenous variable, implicitly assuming that yields are unaffected by the capital flows themselves, even though this can clearly lead to underestimation of the strength of asset demand fluctuations.

Moreover, the country level approach in these articles has the disadvantage that the push factors may be underestimated because flows from all host countries are included but only US factors are considered. In consequence, some authors have examined the capital outflows to emerging markets from the USA alone. Taylor and Sarno (1997) examine the determinants of US portfolio capital outflows towards Latin America and Asia using cointegration techniques. They find that global ("push") and domestic ("pull") factors have similar importance in explaining short-run equity flows to Asia and Latin America. However, for the shortrun dynamics of bond flows, global factors (particularly US interest rates) are found to be more important than domestic factors. Chuhan et al. (1998) model US portfolio flows to Latin American and Asian markets, using the panel data method. They find, in contrast, that push factors (the slowdown in US industrial production and the drop in US interest rates) are the main determinants of portfolio flows to Latin America and Asia.

The only attempt so far to model asset demand and supply effects in conjunction is an innovative disequilibrium model of capital flows to four emerging markets - Brazil, Mexico, Thailand and Korea - in Mody and Taylor (2002). They derive this model from the seminal Stiglitz-Weiss (1981) theory of credit rationing, which allows for such market disequilibria explicitly. Using the maximum likelihood estimation technique, they estimate push and pull factors ${ }^{4}$ separately for capital flows for each country. The technique then estimates the probability of asset supply exceeding demand at any one point in time, which the authors term a 
"capital crunch". The demand factors include shortterm and long-term US interest rates, the US high yield spread and US industrial production; while supply factors include the international cost of capital (proxied by the mean emerging market bond yields, host stock market indices and reserve levels. They find that the demand for emerging market assets operates through two distinct channels: on the one hand, US industrial production growth raises the supply of capital (that is, the demand for assets); on the other, increased US high-yield reduces it - which they interpret as reflecting the opportunity cost of US risk capital. This model marks a significant step forward from the singleequation push-pull model, particularly the explicit handling of capital rationing. However, there are two aspects where our approach differs from that of Mody and Taylor. First, the negative impact of the US high-yield spread on flows to emerging markets indicates that what is being captured is changes in risk aversion; and second, the inclusion of emerging market yield spreads as an independent variable overlooks the fact that flows can clearly affect spreads inversely.

In sum, while the recent literature throws valuable light on the influence of home shocks on capital flows to emerging markets, it is incorrect in taking the yield spread to be an independent variable. Even the IMF admits that 'the stance and predictability of US monetary policy is important in explaining fluctuations in developing country interest rate spreads' (IMF 2000: 68). This is supported by the recent literature on the determination of emerging market bond spreads themselves. Eichengreen and Mody (1998) modelled these spreads as a function of global economic conditions (proxied by the rate on 10year US treasuries) and issuer characteristics of the borrower such as region, whether it is sovereign, and macroeconomic characteristics. Curiously, they find that a rise in US interest rates is associated not only with a lower probability of a bond issue (i.e. primary asset supply) which theory predicts, but also with reduced spreads which it does not. However, when Arora and Cerisola (2000) estimated the influence on country risk (proxied by sovereign bond spreads) of US monetary policy, host fundamentals, and world capital market conditions they found that this ambiguous result was due to proxying US monetary policy by the yield on Treasury securities. When the US Federal Funds target rate was used, they found direct positive effects on sovereign bond spreads, as theory anticipates. Nonetheless, this particular literature does not seem to take into account the effect of capital flows themselves as asset prices and debt levels, and thus yield spreads.

\section{Accounting for portfolio investor behaviour}

There are strong explicit indications that home factors affect both flows and spreads - in fact the IMF (2000) suggests that about half of their observed variance can be explained by these factors - but also the implication that flows and spreads are co-determined. This does not just mean that they should be modelled simultaneously but also that aggregate market interactions may cause additional instability - with serious consequences for developing countries.

The logic of home portfolio investor behaviour in response to market signals also has significant consequences for the pricing of developing country assets, quite independently of the underlying fundamentals. Recent work on herding by investors indicates that three causes can be involved (Devenow and Welch 1996). First, payoff externalities where payoff to an agent adopting an action is positively related to the number of agents adopting the same action. Second, principle-agent considerations such that a manager, in order to maintain or gain reputation when markets are imperfectly informed, may prefer either to "hide in the herd" to avoid evaluation or "ride the herd" in order to improve reputation. And third, information cascades where later agents, inferring information from the actions of prior agents, optimally decide to ignore their own information. Moreover, asset valuation methods and portfolio composition rules used by investors in practice tend to be rather crude, being largely based on considerations of liquidity and exit possibilities (Clark et al. 1993).

There are thus severe limitations to the use of yield spreads on emerging market bonds, as evidence of markets perception of asset quality in the form of underlying default risk: "care is needed in interpreting yield spreads, since they are influenced by a variety of factors other than the perceived creditworthiness of the borrower including investors' appetite for risk and the liquidity of particular instruments' (Cunningham et al. 2001: 175). 
Figure 1: US Gross Purchases of Developing Country Bonds (LTBDC) and their Yield Spread over US Treasuries (Spread_EM) between 1987 and 2002

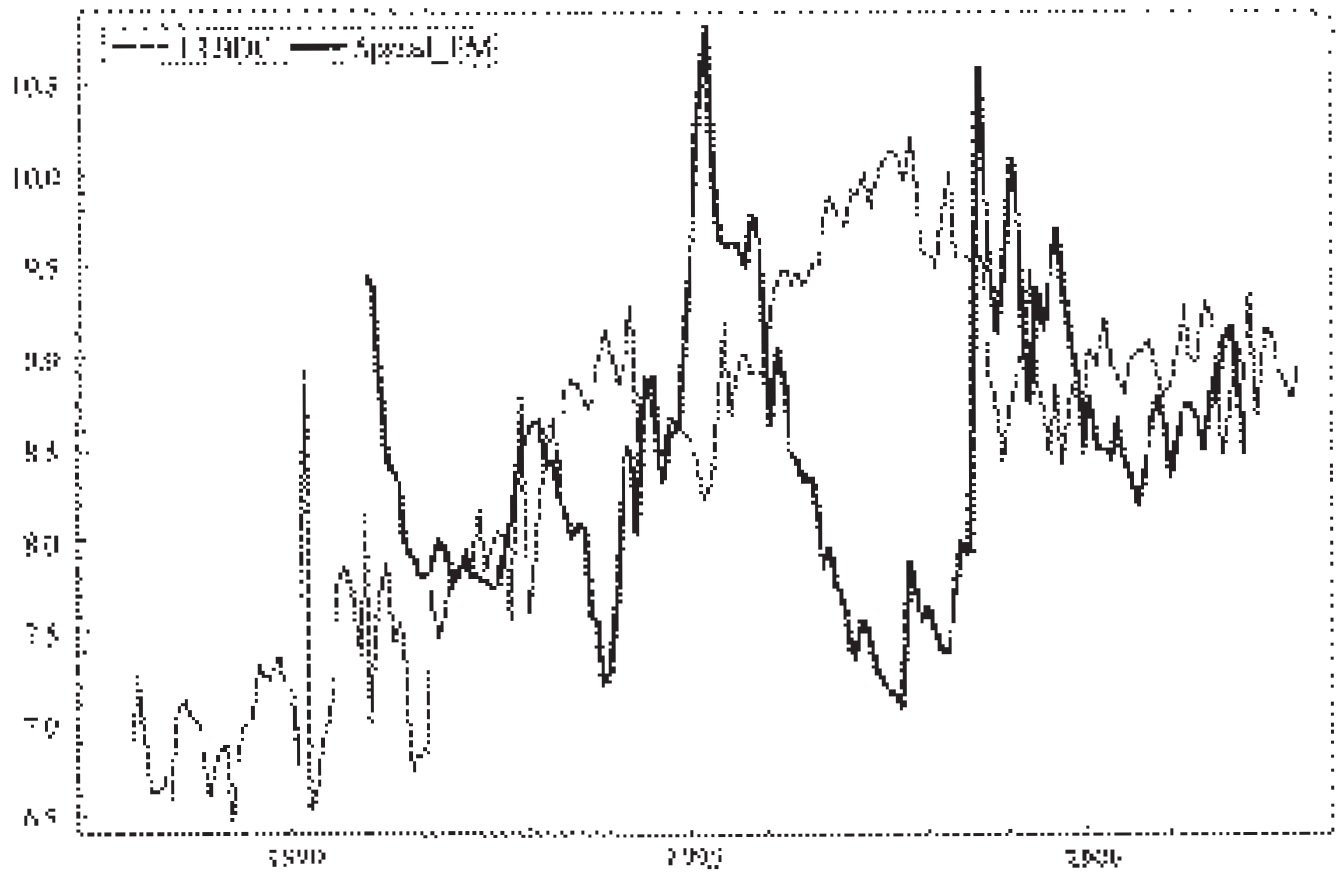

Note: LTBDC in logarithmic form, and Spread_EM in per cent.

Source: US Treasury and Bloomburg.

Clearly higher home interest rates, lower volatility in home assets, higher covariance between these and emerging market assets, and higher risk aversion will all reduce demand for emerging market assets independently of the supply conditions (Disyatat and Gelos 2001). Further, pervasive herding behaviour causes a "momentum" effect in which demand for an asset becomes a positive function of the quantity (capital flow) itself. There is thus good reason to see risk aversion (or "risk appetite") as a variable in itself, which is not only changing but also path dependent, varying with past experience of yields and bubbles and thus potentially strongly pro-cyclical. For instance, the IMF recognises that risk aversion changes over time in practice and uses, for this purpose, the JP Morgan Global Risk Aversion Index (IMF 2001), which measures monetary liquidity and credit premia.

Econometric analysis of US mutual fund portfolios shows that their momentum trading in emerging market equities is positive - they systematically buy winners and sell losers (Kaminsky et al. 2000). Investors also engage in "contagion trading" - that is they sell assets from one country when asset prices fall in another - and "benchmarking", where they follow the average portfolio choices of the market as a whole. Disyatat and Gelos (2001) also found that benchmarking explains observed behaviour of US mutual funds specialising in emerging markets better than the textbook rebalancing rule. The consequence is that when emerging market asset prices are rising (i.e. yield spreads are falling) investors will buy more, rather than rebalancing their portfolios towards assets with a higher return. The reverse occurs when prices are falling, causing large market fluctuations known as "bubbles" that are not caused by fundamentals in either the home or host markets.

Kumar and Persaud (2001) have pointed out that changes in risk aversion - or its counterpart, risk appetite - have received comparatively little attention in the academic literature, even though 


\section{Figure 2: US Gross Purchases of Developing Country Bonds (LTBDC) and US High-Yield Spread (Spread_HY) between 1987 and 2002}

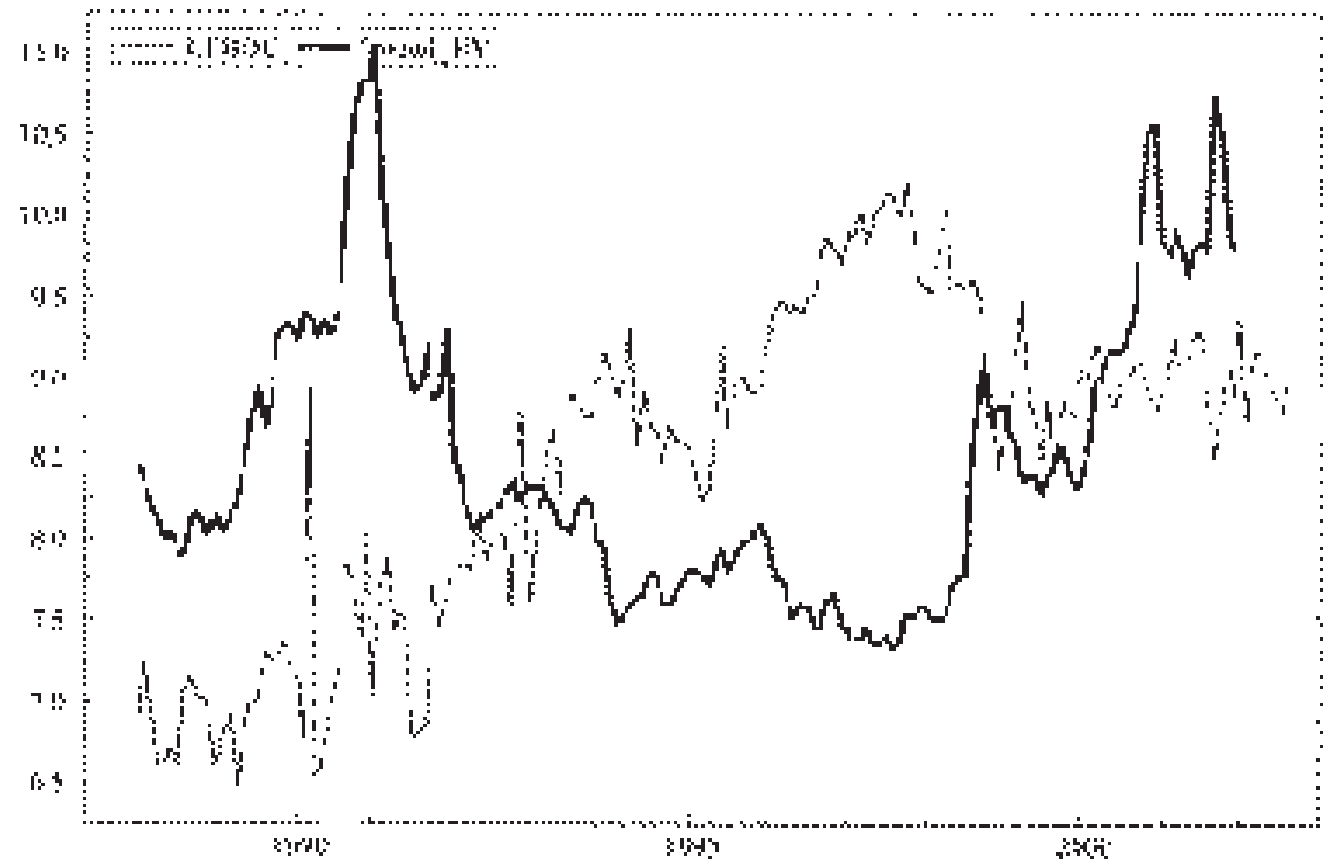

Note: LTBDC in logarithmic form, and Spread_HY in per cent.

Source: US Treasury and Bloomburg.

discussed in market and policy circles. ${ }^{5}$ They argue that risk aversion contains structural components (the underlying utility function and financial market structure) and a time varying element reflecting shorter-term factors such as so-called "wake-up calls". Clearly, not only does a rise in risk aversion (fall in risk appetite) ${ }^{6}$ cause a fall in asset price for a given risk level, but also the impact on price will be greater for riskier asset classes. Applying this argument to our context, to the extent that home risk aversion is reflected in US risk spreads, then the same change in risk appetite would be reflected in Emerging Market spreads, as well as in the aggregate flows due to the capital market rationing effect.

To encompass these microeconomic aspects of investor behaviour, and taking into account the characteristics of aggregate capital flows discussed in the previous section, it should be clear that a model for empirical testing should have the following five characteristics:
1. Spreads impact flows negatively because of the risk information they contain; while flows impact spreads negatively because increased demand drives up the price.

2. Risk aversion varies over time, and affects flows negatively due to asymmetric rationing, and yield spreads positively due to risk pricing.

3. There are lagged effects of past-on-present flows due to momentum trading, and past-on-present spreads due to asset bubbles.

4. The familiar home variables such as riskless return and wealth (or liquidity) and host variables to reflect fundamentals such as real return and probability of default, are included.

5. A simultaneous equation system to capture the interaction of price (yield spread) and quantity (capital flow) in equilibrium. 
Figure 3: US High-Yield Spread (Spread_HY) and Developing Country Yield Spread over US Treasuries (Spread_EM) between 1987 and 2002
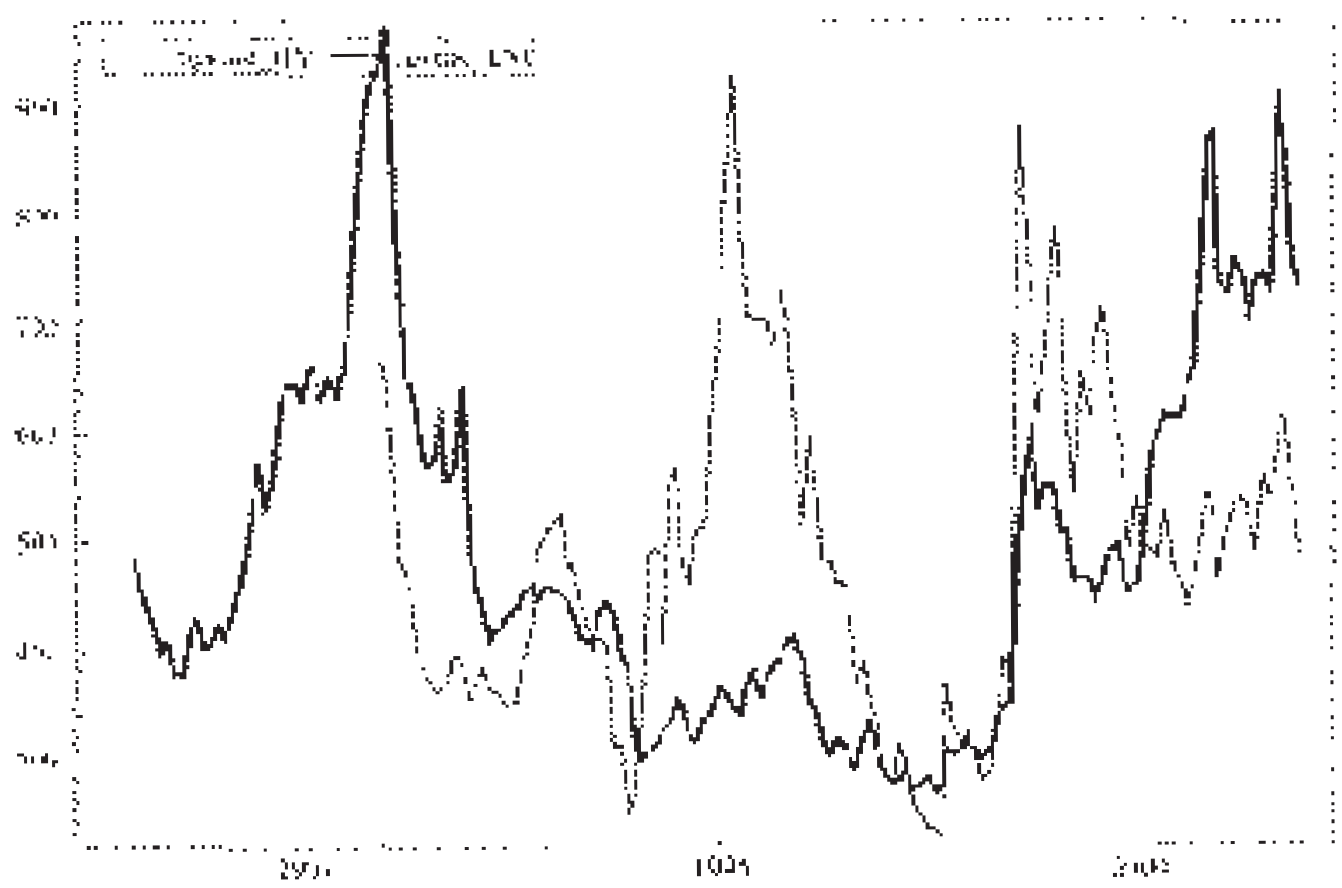

Note: Spread_HY and Spread_EM in basis points (hundredths of a per cent).

Source: US Treasury and Bloomburg.

\section{Testing of the new model of capital flows to developing countries}

The model discussed above has been tested on monthly 1987-2003 data for total US bond flows to developing countries from the US Treasury Department's International Capital Reports and EMBI (Emerging Markets Bond Index) data on sovereign spreads from Bloomburg. ${ }^{7}$ Technical details of data processing, econometric method and diagnostics can be found in FitzGerald and Krolzig (2003a). Figure 1 shows the main characteristics of flows and spreads that the model must explain: the high level of volatility and the inverse relationship between the two.

Our data source for risk aversion is the US highyield spread (HYS). This is plotted against bond flows in Figure 2, where the inverse relationship is evident. In view of the relative size of the two markets, any causality must presumably run from the US home market to emerging markets rather than the other way around.
The exact formulation of the proxy variable for risk aversion from the HYS data is complicated. The discussion in the previous section implies that the data should be used to produce a risk aversion measure such as the ratio of the mean to the standard deviation which would be equivalent to the "Sharpe Ratio" used in practice to express a particular investor's balance between risk and return. ${ }^{8}$ However, it appears from the literature that changes in HYS itself are the best empirical representation of risk aversion. Figure 3 shows the relationship between the spread between high yield ("junk") bonds and treasury bills on the US market on the one hand and the spread between developing country bond yields and US treasuries on the other. The relationship between the two is clearly quite close.

The econometric modelling of these relationships is explained in detail in FitzGerald and Krolzig (2003a). ${ }^{9}$ In explaining aggregate bond flows, the flow in the previous month is the major explanatory variable, with high degree of persistence (60 per 
cent) reflecting momentum trading. This helps explain why the fluctuations are so large. The effect of spreads on flows is also significant and of the negative sign predicted by our model, because of the risk premium it contains. The measure of risk aversion, the change in HYS for the previous month is also significant and of the expected negative sign, thus supporting our notion of risk aversion and credit rationing - the lag presumably reflecting portfolio adjustment delays. US industrial production (as a proxy for monthly GDP) was significant and with the correct sign, reflecting the hypothesised wealth effect, while the results for the Federal Funds rate appear to reflect the influence of changes at the 6-weekly meeting of the Open Markets Committee. However, the outstanding bond stock and aggregate merging market liquidity, included as a proxy for fundamentals for developing countries as a whole, did not prove significant.

The major explanator of yield spreads is lagged yield spread itself, with the expected (positive) sign and a very high degree of persistence (84 per cent) presumably reflecting the asset bubbles discussed above. In other words, asset prices are mainly determined by the previous month's level. As anticipated, bond flows themselves are a significant variable, with the negative sign predicted above. Again, as in the case of flows, the change in HYS as a measure of home risk aversion itself is significant and has expected (positive) sign. It is of interest to note that the US variables (funds rate, liquidity, output) did not turn out to be significant in explaining the yield spread: the effect of these variables is felt on the flow of bonds and this appears to confirm the view that this is a rationed credit market where shocks affect quantity rather than price. Interestingly in view of the number of emerging market crises during this period, only one seems to have been econometrically significant - that for the Russian collapse in August 1998.

Overall, this model can explain 81 per cent of observed variations in bond flows and 87 per cent of those in yield spreads. This implies that by far the greater part of emerging bond market volatility is explained by market interactions (expressed by the persistence in flows and spreads as well as their lagged effect on each other) on the one hand; and the combination of home risk aversion, home interest rates and home income levels on the other. In other words as far as this asset class as a whole is concerned, shifts in the demand schedule and their effects are more significant than overall fundamentals. This could be because investors apply a portfolio allocation procedure in two stages: first they allocate funds to emerging markets as an asset class, with US risk appetite and interest rates interacting with the yield spread - which itself is a result of these same flows; second, investors allocate their purchases between individual emerging markets in response to the fundamentals these markets demonstrate.

\section{Policy implications}

These are clearly initial results, although they are clearly significant. The next research step is to test a similar model on flows to individual emerging markets - and preliminary results indicate that here too a simultaneous-equation approach is fruitful and that host fundamentals are significant determinants of the share of bond flows going to a particular country. ${ }^{10}$ This seems to confirm the validity of a twostage modelling approach reflecting portfolio strategies where investors allocate funds to emerging markets as an asset class, and then between countries - where macroeconomic characteristics and regional factors determine country shares.

Meanwhile, the main result is that shifts in the international demand schedule for developing country assets, magnified by the behavioural characteristics of investment managers, are the main determinants of the market volatility that has caused so much difficulty for the attainment of sustainable economic development and thus permanent poverty reduction. Five tentative policy implications would seem to follow logically from this conclusion.

First, the strong evidence for momentum trading and price bubbles (reflected in the extent of the persistence in the flow and spread models detailed above) implies that there are considerable costs for developing countries of way in which markets operate internally. This problem could be tackled by more detailed knowledge of developing countries and independent decision-making by investment managers, but there is no reason to believe that they will do this unless the regulatory framework is modified in order to provide incentives for them to do so.

Second, G3 governments ${ }^{11}$ could pay more attention to the negative effects on emerging markets of volatility within their own capital markets. As the IMF points out, 'an approach to monetary policy that provides financial markets with clear indications 
of the US authorities' intentions is likely to reduce the impact of a US rate increase on developing countries' (IMF 2000: 68). However, the ability of the G3 to stabilise or even predict their macroeconomic cycles - let alone their willingness to intervene in their own capital markets to benefit developing countries - is clearly limited.

Third, a more feasible approach might be to encourage G3 institutional investors to acquire and hold emerging market assets of a longer maturity than at present, by regulatory or even tax incentives. This would in effect both shift the demand "upwards" and reduce its volatility over the cycle by increasing risk appetite on a structural basis. The advantages to institutional investors would be higher long-term yields without the excess risk generated by the market instability of the past decade.

Fourth, greater liquidity - and thus more stability - in the developing country bond market could be achieved by the international financial institutions themselves or groups of central banks (probably on a regional basis) acting as "market makers". They

\section{Notes}

* I would like to acknowledge the invaluable econometric and statistical support of Derya Krolzig in this research project: the full econometric results are available in FitzGerald and Krolzig (2003a). Research for this article was funded by the UK Department for International Development (DFID) under the Globalisation and Poverty Programme. I would also like to thank Stephany Griffith-Jones for her inspiration and support for this research.

1. See Stiglitz and Weiss (1992) for a fuller discussion of the macroeconomic consequences of credit rationing, and Folkerts-Landau (1985) for a pioneering application to international credit markets.

2. Although, Chuhan et al. (1998) point out that reserves are only weakly correlated with portfolio capital flows and so should not really be used as a proxy.

3. The difference between the yield on sub-investment grade ("junk") bonds and 10-year US Treasuries.

4. They refer to these as "capital supply" and "capital demand" respectively, which is not uncommon in the literature - but I feel that "asset demand" (and by implication "asset supply") is the only nomenclature consistent with the underlying portfolio decisions made by investors.

5. One reason for this may be that standard neoclassical theory derives risk aversion from the underlying utility function of the "representative agent", which is assumed to be invariant - unlike of course Keynesian "animal spirits". would commit to counter-cyclical intervention, buying bonds on the secondary market on the downswing (when risk appetite declines) and selling on the upswing. This would be more effective than the present practice of last-resort lending once crises have occurred, since it would reduce the ex-ante volatility of emerging market assets.

Fifth, the last option in the absence of international cooperation would be intervention by individual developing countries. These could take the form of prudential restrictions borrowing on international capital markets by governments, banks and firms; but this would deny developing countries the opportunity to manage macroeconomic shocks arising from trade, productivity or fiscal shocks. Capital controls in the form of tax incentives can be effective as a means of reducing the volatility of foreign investors' holding of domestic securities on developing country stock markets. However, such incentives can have little effect on international bond issues precisely because they are traded globally in New York and London.

6. Kumar and Persaud estimate risk appetite by calculating excess returns (the difference between spot rates and forward rates from the previous period) on 17 emerging market currencies over 10 years. Their risk appetite index exhibits marked quarterly and annual cycles, and troughs that appear to be correlated with major market discontinuities.

7. The data for other explanatory variables come from various sources: International Financial Statistics (US Industrial Production Index), Bloomberg (US high-yield spread), US Federal Reserve System (M3 US Money Stock, US Federal Funds Rate), and Cross Border Capital (Emerging Market Liquidity Index).

8. See Caouette et al. (1998: 242).

9. The key results are as follows for flows (LTBDC) and spreads (Spread_EM) respectively:

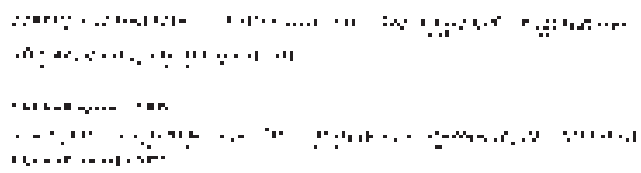

where the explanatory variables are change in US industrial production index ( $\Delta$ LIIP), the Federal Funds rate (FedFunds), the change in the US high-yield spread $(\Delta$ Spread_HY) and an impulse dummy (I) significant breaks in the series.

10. Preliminary results are reported in FitzGerald and Krolzig (2003b).

11. That is, those of the US, EU and Japan. 


\section{References}

Arora, V. and Cerisola, M., 2000, 'How does US monetary policy influence economic conditions in emerging markets?', IMF Working Paper 00/148

Calvo, G.A., Leiderman, L. and Reinhart, C.M., 1993, 'Capital inflows and real exchange rate appreciation in Latin America: the role of external factors', IMF Staff Papers 40: 108-151

Caouette, J.B., Altman, E.I. and Narayan, P., 1998, Managing Credit Risk: The Next Great Financial Challenge, New York: Wiley

Chuhan, P., Claessens, S. and Mamingi, N., 1998, 'Equity and bond flows to Latin America and Asia: the role of global and country factors', Journal of Development Economics, Vol 55: 439-463

Clark, E., Levasseu, M. and Rousseau, P., 1993, International Finance, London: Chapman and Hall

Cunningham, A., Dixon, L. and Hayes, S., 2001, 'Analysing yield spreads on emerging market sovereign bonds', Bank of England Financial Stability Review: 175-186

Devenow, A. and Welch, I., 1996, 'Rational herding in financial economics', European Economic Review, Vol 40 Nos 3-5: 603-16

Disyatat, P. and Gelos, R.G., 2001, 'The asset allocation of emerging market funds', IMF Working Paper 01/11

Dumas, B., 1994, 'Partial Equilibrium Versus General Equilibrium Models of the International Capital Market', in F. van der Ploeg (ed.), The Handbook of International Macroeconomics, Oxford: Blackwell: 301-334

Eichengreen, B. and Mody, A., 1998, 'What explains changing spreads on emerging-market debt: fundamentals or market sentiment?', National Bureau of Economic Research Working Paper 6408

Fernandez-Arias, E., 1996, 'The new wave of private capital inflows: push or pull', Journal of Development Economics 48: 389-418

FitzGerald, E.V.K., 2002, 'The Instability of the Emerging Markets Asset Demand Schedule', in R. Ffrench-Davis and S. Griffith-Jones (eds), Capital Flows to Emerging Markets Since the Asian Crisis, Oxford: Oxford University Press for UNU/WIDER

FitzGerald, E.V.K., 2001, 'Short-term Capital Flows, the Real Economy and Income Distribution in Developing Countries', in S. Griffith-Jones, M.
Montes and A. Nasution (eds), Short-Term Capital Flows and Economic Crises, Oxford: Oxford University Press for UNU/WIDER: 29-51

FitzGerald, E.V.K. and Krolzig, D., 2003a, 'Modelling the demand for emerging market assets', Oxford University, Financial Economics Working Paper 2003-FE-10, www.finance.ox.ac.uk/papers.htm (accessed September 2003)

FitzGerald, E.V.K. and Krolzig, D., 2003b, 'The simultaneous determination of emerging markets bond flows and yield spreads', Oxford University, Financial Economics Working Paper 2003-FE-XX, www.finance.ox.ac.uk/papers.htm

Folkerts-Landau, D., 1985, 'The changing role of international bank lending in development finance', IMF Staff Papers 32: 317-363

IMF, 2001, Emerging Market Financing, Washington, DC: International Monetary Fund

IMF, 2000, World Economic Outlook, Washington, DC: International Monetary Fund

IMF, 1995, Institutional Investor Behaviour and the Pricing of Developing Country Stocks, Washington, DC: International Monetary Fund

Kaminsky, G., Lyons, R.K. and Schmukler, S., 2000, 'Managers, investors, and crises: mutual fund strategies in emerging markets', NBER Working Paper 7855

Kumar, M.S. and Persaud, A., 2001, 'Pure contagion and investors' shifting risk appetite: analytical issues and empirical evidence', IMF Working Paper 01/134

Mody, A. and Taylor, M.P., 2002, 'International capital crunches: the time-varying role of informational asymmetries', IMF Working Paper $02 / 43$

Mody, A., Taylor, M.P. and Kim, J.Y., 2001, 'Modelling fundamentals for forecasting capital flows to emerging markets', International Journal of Finance and Economics 6: 201-16

Montiel, P. and Reinhart, C.M., 2001, 'The Dynamics of Capital Movements in Emerging Economies During the 1990s', in S. Griffith-Jones, M.F. Montes and A. Nasution (eds), Short-term Capital Flows and Economic Crises, Oxford: Oxford University Press for UNU/WIDER: 3-28

Montiel, P. and Reinhart, C.M., 1999, 'Do capital controls and macroeconomic policies influence the volume and composition of capital flows? Evidence from the 1990s', Journal of International Money and Finance 18: 619-635 
Stiglitz, J. and Weiss, A., 1981, 'Credit rationing in markets with imperfect information', American Economic Review 71: 393-410

Stiglitz, J. and Weiss, A., 1992, 'Asymmetric information in credit markets and its implications for macroeconomics', Oxford Economic Papers 44: 694-724
Taylor, M.P. and Sarno, L., 1997, 'Capital flows to developing countries: long- and short-term determinants', The World Bank Economic Review 11: 451-470 